\section{【総 説】}

レギュラトリーサイエンスの 視点からみた医薬品と保健機 能食品における有効性又は安 全性の科学的根拠に必要な規 制やその考え方の相違 Differences on the Regulation between Foods with Health Claims and Ethical Pharmaceuticals from the Viewpoint of Regulatory Science

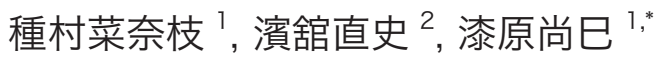
Nanae TANEMURA ${ }^{?}$, Naobumi HAMADATE², Hisashi URUSHIHARA ${ }^{1, *}$

1 慶應義塾大学薬学部

2 濱舘学術事務所

\section{【要 旨】}

現在, 健康寿命の延伸が重要とされ, セルフメディケー ションが推進されている. その推進の一助として保健機 能食品の活用が提案されている. しかし，食品が持つ機 能性関与成分は多様であるため, 科学的根拠を示すため に必要な臨床試験における評価系を考察することは重要 である. 本稿では, 保健機能食品の定義や制度変遷, 及 びその種類や特徵を解説した後で, 安全性又は有効性の 科学的根拠に関し医薬品との考え方の違いを解説する. 今後，透明性のある明確化された基準に基づき保健機能
食品に関する制度を成熟させていくことで，消費者 の信頼を確保することができ, 今後さらなる市場の 活性化に繫がると確信する.

【キーワード】

レギュラトリーサイエンス, 健康強調表示, 保健機 能食品, 医薬品, 有効性, 安全性, 評価, 臨床試験, 食品, 日本

\section{はじめに}

現在，高齢化による医療費増大のため，自分自身で健 康を管理するセルフメディケーションにより健康寿命を 延伸させていくことが重要となっている，そのセルフメ ディケーションの一つとして保健機能食品の利用があげ られる。しかし，食品が持つ機能性関与成分は多様であ るため，医薬品のように明確なエンドポイントや大多数 に広く納得される定義はない ${ }^{1)}$ 。その一方, 清水(2015)は, 食品機能の科学的根拠として適切な臨床試験での有効性 の確認が必要であり, in vitro 試験や in Vivo 試験では十 分でない ${ }^{2)}$ ，と述べている。 そこで，我々は保健機能食 品を開発するにあたり，その科学的根拠を示すために必 要とされる臨床試験における安全性又は有効性の評価系 をレギュラトリーサイエンスの視点から考察することが 重要であると考える ${ }^{3)}$.レギュラトリーサイエンスとは, 内山（1996）により”規制政策に科学的根拠を与える「行 政科学」の側面と，既存の基礎科学や応用科学とは異な る「評価科学」の側面をあわせもちつつ，科学の所産を 人間との調和の上でもつとも望ましい姿に調整し方向づ けるための科学”4)，と定義された新しい学問領域のこと である。

本稿では，保健機能食品の定義や制度変遷に始まり， その種類や特徵を解説した後で, 臨床試験における安全 性又は有効性の科学的根拠に関して医薬品との考え方の 違いを解説する。

\section{1. 人が食する物の定義（図 1）}

人が食するものは，大きく医薬品，医薬部外品（以下， 医薬品等）と食品とに大別される。また，日常生活にお いて食品は，消費者に非常に身近な存在である，食品の

\begin{tabular}{|c|c|c|c|c|}
\hline \multicolumn{5}{|c|}{ 人が食する物 } \\
\hline 医薬品等 & \multicolumn{4}{|c|}{ 食品 } \\
\hline \multirow{2}{*}{$\begin{array}{l}\text { 医薬品 } \\
\text { 医薬部外品 }\end{array}$} & $\begin{array}{c}\text { 特定保健 } \\
\text { 用食品 }\end{array}$ & $\begin{array}{c}\text { 栄養機能 } \\
\text { 食品 }\end{array}$ & $\begin{array}{l}\text { 機能性表 } \\
\text { 示食品 }\end{array}$ & \multirow{2}{*}{ いわ般食品 } \\
\hline & \multicolumn{3}{|c|}{ 保健機能食品 } & \\
\hline
\end{tabular}

図 1 医薬品等と食品との違い 
機能は, 1 次機能, 2 次機能, 3 次機能と 3 つの機能があ る. 1 次機能は栄養面での働き, 2 次機能は嗜好面での働 き，そして 3 次機能は健康の維持・増進における生体調節 での働きである。保健機能食品は，3 次機能を有する食品 と定義された ${ }^{5)}$. 一般食品と保健機能食品を除いた「いわ ゆる健康食品」は，機能性関与成分を訴求した表示が一切 できない。「いわゆる健康食品」の全てがかつて健康被害 をもたらしたような粗悪品ではないが，保健機能食品が定 義されたことにより「いわゆる健康食品」との差別化が可 能となった ${ }^{6}$. 結果として，消費者の保護や市場整理が期 待されている ${ }^{7)}$ 。一方で, 2014 年の消費者庁が公表した「食 品の機能性表示に関する消費者意向等調査結果」では，最 近 1 年間に「健康食品」を摂取したことがある者の割合は 全体の $43.8 \%$ にのぼり，うち $26.6 \%$ は，健康食品のうち 特定保健用食品, 栄養機能食品といつた，どのカテゴリの 食品を摂取したのかは分からないと回答していた ${ }^{8)}$ 。よつ て,「いわゆる健康食品」と差別化し, 保健機能食品の利 用を促進するためには消費者教育が重要であろう ${ }^{3)}$.

\section{2. 日本における保健機能食品に関する制度の変遷(図 2)}

医薬品とみなされるべき物が食品の名目のもとに製造さ れている状況を改善するために，1971 年に厚生労働省よ り「無承認無許可医薬品の指導取締りについて」 ${ }^{9)}$ が発出 され, 食品の機能性表示は不可能となった。しかし, 文部 科学省の研究班による「食品機能の系統的解析と展開 (1984 - 1986 年)」 ${ }^{5)}$ の成果を得て，1991 年に特定保健用食品 制度が開始され，食品の機能性表示が可能となった。その 後，1993 年に世界で初めて，3 次機能を有する 2 つの食
品が誕生し, 国際学術誌でも紹介された ${ }^{10)}$.しかし，一方 で日本が定義した Functional Foodの用語は, 国際的な認 知を獲得するまでに時間を要し ${ }^{2)}, 1996$ 年の欧州 FUFOSE プロジェクト (The European Commission Concerted Action on Functional Foods Science in Europe) ${ }^{11)}$ をきっ かけに，世界的にこの用語が使用されるようになった。続 いて，2001 年に栄養機能食品制度が設けられ，2009 年よ り制度の管轄が厚生労働省より消費者庁へ移行した。その 後, 2013 年より機能性をもつ農林水産物・食品開発プロジェ クトが，北海道フード・コンプレックス国際戦略総合特区 の北海道食品機能性表示制度（通称「ヘルシーDo」） ${ }^{12)}$ と して開始された。これらは, 生鮮食品も対象となる機能性 表示食品制度の先行モデルとなつた。さらに 2015 年より 食品表示法が施行され，機能性表示食品制度が始まったが, この機能性表示食品制度に限定して，ヘルシーDo と併用 が可能である。このように我が国の保健機能食品制度は, 現在に至るまで世界をリードしてきたと言えよう。

\section{3. 日本における保健機能食品の種類}

\section{1 ) 特定保健用食品}

特定保健用食品制度は，世界に先駆けた健康強調表示制 度の始まりとなった個別審査型の制度である。保健の用途 範囲では, 「医薬品, 医療機器等の品質, 有効性及び安全 性の確保等に関する法律 (薬機法)」にて定める疾病の診断・ 治療・予防に言及しない範囲の食品の機能を科学的根拠に 基づき表示することが許可される ${ }^{13)}$. 現在の管轄省庁は消 費者庁であるが, 当初は厚生労働省であった. 2001 年には, 錠剤やカプセルといつた製品形態も許可されるようになつ

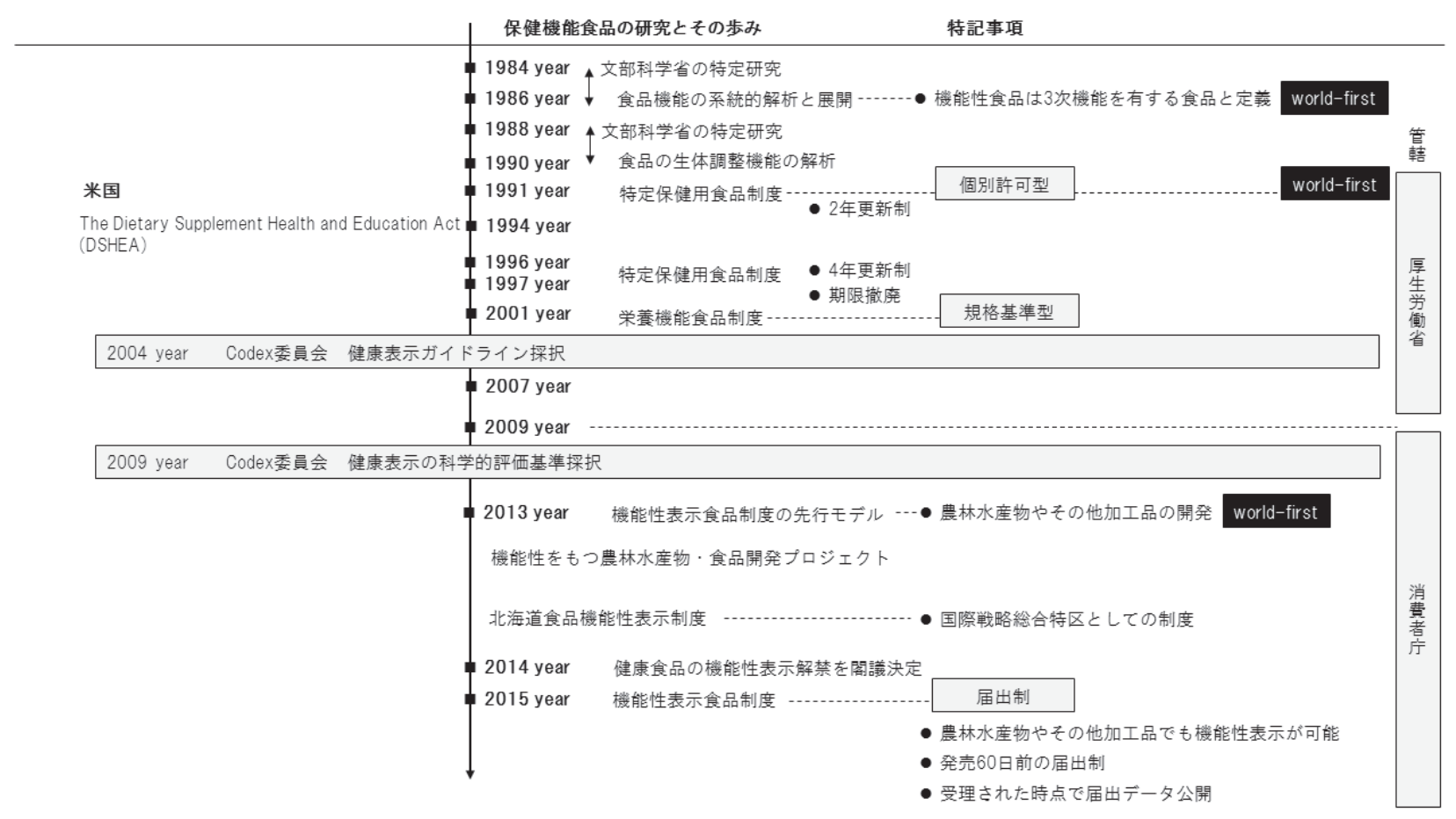

図 2 日本における保健機能食品に関する制度の変遷 
た ${ }^{2)}$. 許可要件として，1) 臨床試験により有効性が示され ていること，2) 食経験や安全性試験により安全性が確保さ れていること，3) 機能性関与成分の定量化，といった要件 を全て満たす必要がある2).

\section{2 ）栄養機能食品}

栄養機能食品制度は，食品の成分が一定の基準内であれ ば届出が不要となる規格基準型の制度である。対象成分と しては，ビ夕ミンなどが該当する。下限值は栄養所要量の 3 分の 1 であり, 上限值は医薬部外品の最大量を超えない ものとされている。ささらに，2015 年 4 月より制度化され た機能性表示食品の対象範囲を鑑み，従来は加工食品と鶏 卵が対象であったが生鮮食品も対象となった ${ }^{14)}$.

\section{3 ) 機能性表示食品}

機能性表示食品制度は, 2013 年 6 月の経済再生の規制 改革会議答申にて，米国のダイエタリーサプリメント制度 を参考に ${ }^{2)}$, 企業の責任で科学的根拠に基づき機能を表示 できる制度が提案され，閣議決定された ${ }^{15)}$ ，その後，消費 者庁が設置した検討会を得て, 2015 年 4 月より食品表示 法（平成 25 年法律第 70 号）に基づく食品表示基準に従っ た制度として開始された。この制度では，特定保健用食品 と同様に食品の 3 次機能が訴求でき, 疾病に至らない健常 者から境界域者を対象とする ${ }^{14)}$. 食品全般が対象であるが, 特別用途食品及び栄養機能食品やアルコールを含有する飲 料, 過剩摂取が国民の健康保持増進に負の影響を与えるも のは対象とはならない ${ }^{14)}$. また, 特定保健用食品との大き な違いは，企業の責任で機能性を訴求できる点や農林水産 物のような生鮮食品も対象となるといつた点である。一方 で，2016 年の機能性農産物の需要動向調査によると機能 性農産物を知らないと回答した消費者は 50.8\%【注】であっ た ${ }^{16)}$ ， と報告されていた。しかし，機能性農産物の市場は， 2015 年度は約 199 億円であったのに対し，2016 年度（予 測）ではその約 1.2 倍，2020 年度（予測）ではその約 1.6 倍と予測されている ${ }^{16)}$. さらに, 従来の特定保健用食品で は，申請に至るまでのハードルや制約も多いため市場が拡 大せず，「いわゆる健康食品」が多く流通したままであっ たため ${ }^{6)}$ ，その差別化は成功しなかった。この新たな制度 により, 食品の持つ 3 次機能に着目した食の機能の利活用 が促進され，健康寿命の延伸に繋がることが期待される。

【注. 調查時期：2016 年 4 5 月, 調査（集計）対象： 国内在住の 20 代 60 代の男女 1,188 名（男性 596 名, 女性 592 名), 調查方法：インターネットアンケート，単 数回答】

\section{4. 臨床試験における有効性又は安全性の評価系に関 する保健機能食品と医薬品との考え方の比較の意義}

食品は，医薬品と異なり多機能性を有し副次的な機能性 が主となる場合があるため ${ }^{17)}$ ，必然的にその評価も難しく なる。現在，保健機能食品の臨床試験における評価系の問
題点として次の 5 つが指摘されている ${ }^{18)}$. 1) 臨床試験の 手段，2）解析，3）被験者の背景，4）二重盲検ランダム化 比較試験の限界，5）遺伝子多型の存在，といつた問題であ る.よって, 医薬品との差異を把握することは, 保健機能 食品における安全性や有効性の評価系をより充実させ信頼 性を高めるために有益であると考える。ただし，制度に関 して全てを比較することは範囲が広くなるため，本稿にお いては焦点を成長戦略の一つとして揭げられ，かつ経済社 会の構造改革を進めることを目的に規制改革会議が提案し た「機能性表示食品」 ${ }^{15)}$ の臨床試験における有効性又は安 全性の評価系に絞り議論する。

\section{5. 機能性表示食品制度の概要}

1 ) 機能性表示食品の届出等に関するガイドライン ${ }^{14)}$

この制度は，企業の責任において科学的根拠を基に機能 性を表示するという, 特定保健用食品等の従来の制度とは 全く異なる制度である. 大きく分けて次の 6 つの点につい て検討を行った上で届出を行うことになる，1) 対象商品と なるかの判断，2) 安全性の根拠，3) 生産・製造及び品質 の管理，4）健康被害の情報収集体制，5）機能性の根拠，6) 表示の内容, といつた点である。 また，既に届出た内容を 変更する際に次の 5 つの点に該当する場合は新規の届出が 必要となり, それ以外は, 変更届出の提出のみとなる。1) 製品の同一性が失われる程度の変更，2) 機能性の変更，3) 機能性関与成分の含有量の変更，4) 摂取目安量の変更，5) 商品名の変更.

\section{2 ）安全性の評価系 ${ }^{14)}$}

まず，喫食実績による食経験の評価を行う。これは，届 出しょうとする食品又は類似する食品についての契食実績 のこと（例 : 類似食品の過去の売り上げ実績, 及びそれに 伴う健康被害報告）である。この実績による評価では不十 分である場合, 既存情報により安全性の評価を行う。この 既存情報とは, 届出しょうとする食品に含有する機能性関 与成分又は最終製品の喫食実績について公的機関のデータ ベースや民間機関等が調査した 2 次情報のことを指す。こ れでも不十分な場合は, 安全性試験を行う必要がある。(図 3 )

\section{3）有効性の評価系 ${ }^{141}$}

有効性の評価は, 研究レビュー又は臨床試験のいずれか の方法（図 4）で行うことになる. 後者は, 保健用途に係 る有効性を確認するために用量設定試験の結果に基づいた 1 日摂取目安量で長期摂取試験を実施する。有効性の根拠 として臨床試験を行った場合は最終的には試験報告書を作 成し，CONSORT 声明に準拠した形で査読付き論文により 報告することが要求されている.

\section{4）安全性に関する一般消費者向け情報}

消費者庁のウェブサイトで公開されている構造化抄録と 


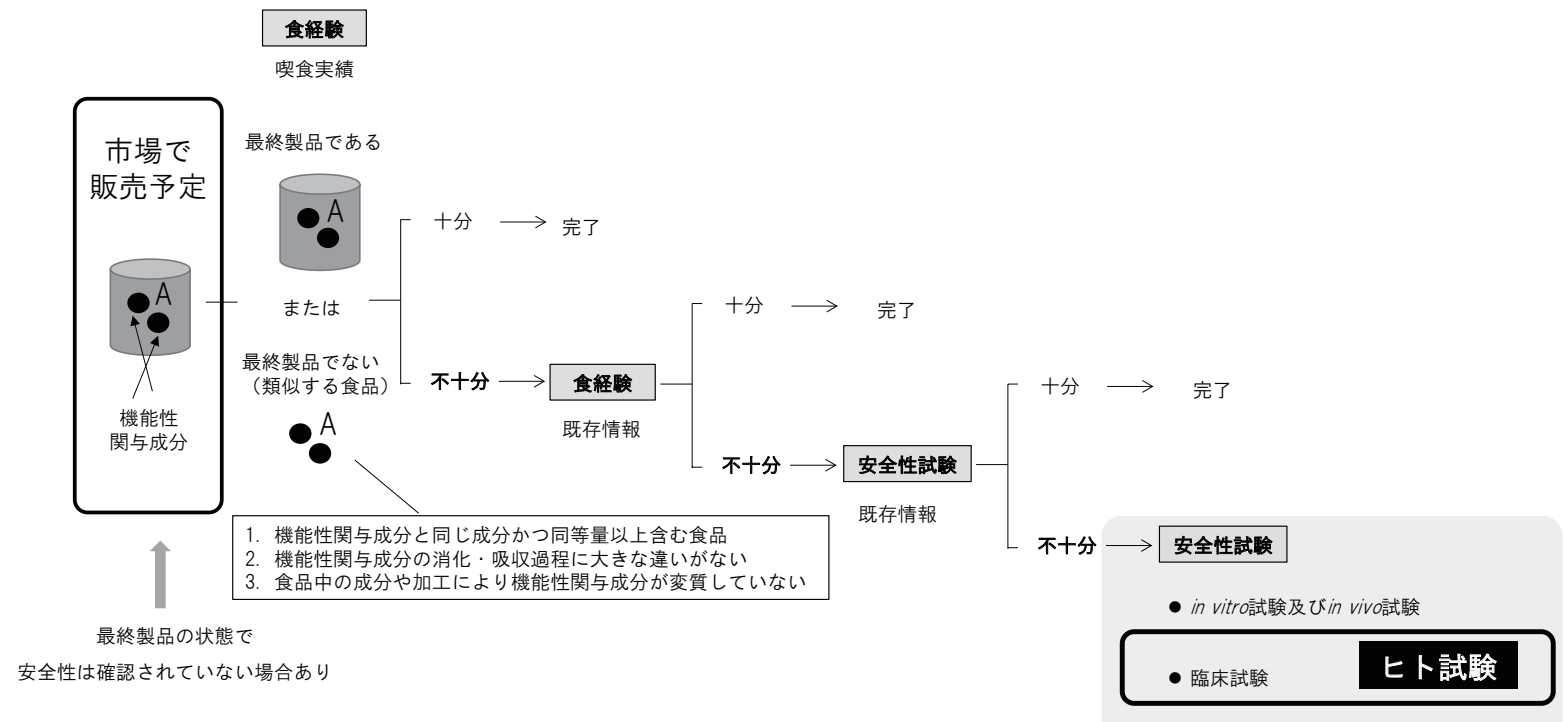

図 3 機能性表示食品の安全性の評価

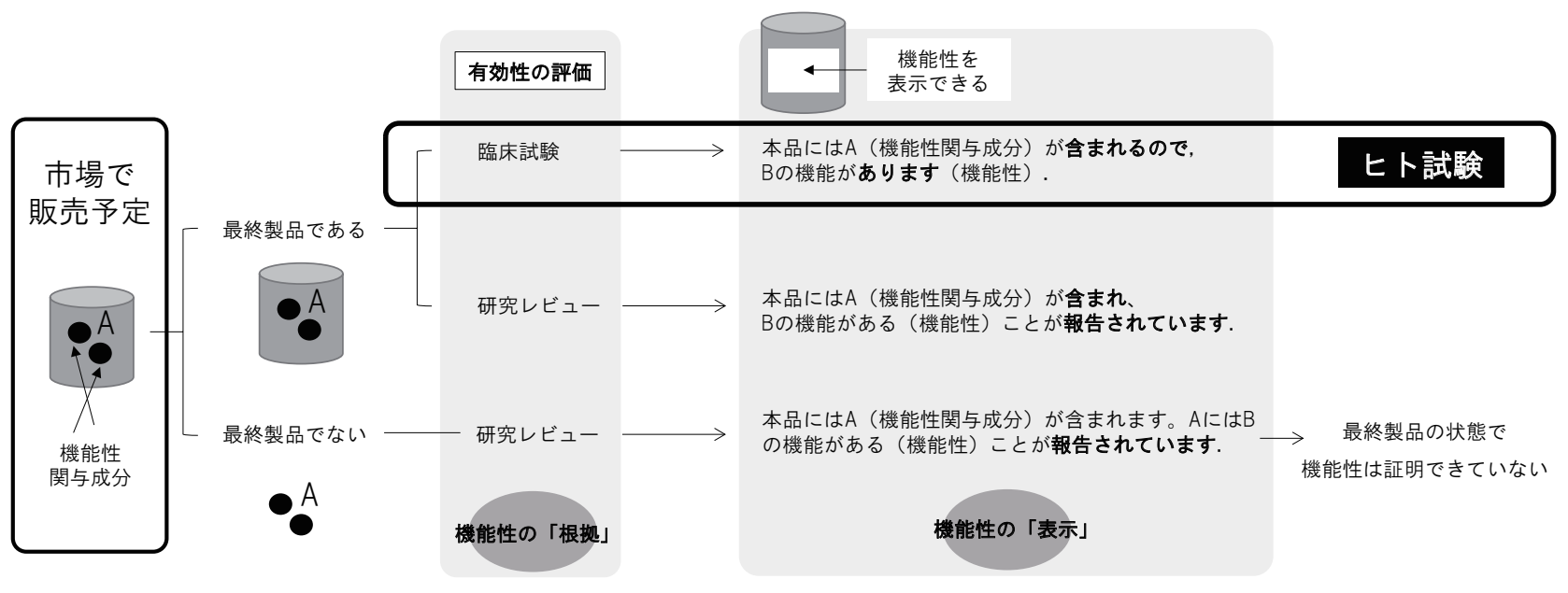

図 4 機能性表示食品の有効性の評価とその表示

呼ばれる「届出食品の科学的根拠等に関する基本情報（一 般消費者向け）」の中の「1。安全性に関する基本情報（図 5)」で一般消費者向けに商品の安全性に関する情報が公開 されている ${ }^{19)}$.

\section{5）有効性に関する一般消費者向け情報}

消費者庁のウェブサイトで公開されている「届出食品 の科学的根拠等に関する基本情報（一般消費者向け）」の 中の「3.機能性に関する基本情報（図 5)」で一般消費者 向けに商品の有効性に関する情報が公開されている ${ }^{19)}$. ま た商品の容器包装に科学的な根拠に基づき機能性を表示 する際には，その根拠を得た過程により表現が異なる（図 4） ${ }^{14)}$. しかし，一般消費者がこれを理解してその違いを 見分けられるかは疑問である。また，〈すりの適正協議会 (2016) が行ったインターネット調査によると ${ }^{20)}$ ，機能性 表示食品を利用したことがない消費者が回答したその理由 として「効果が疑わしいと感じるため」が $37.7 \%$ と最も
多かった。これは, 消費者がその商品の有効性に関する情 報を収集して理解できる環境が整つていないことを示唆す る結果と考える. 一方で, 疾病の治療効果を暗示する表現 や健康の維持増進を越えた表現等は表示できず, また, 薬 機法により表示できる内容は制限される。よって, 例えば 機能性に関する表示に対する消費者の理解度調査を実施す る等, 規制と消費者双方の観点に配慮しながら, 消費者が 表示の内容を理解して自分の力で商品を選択できる仕組み を提案していく必要があると考える。

\section{6）臨床試験において遵守すべき法規則}

食品の臨床試験では, ヘルシンキ宣言と疫学研究に関す る倫理指針の遵守を求めていたが, 後者の指針が 2014 年 に改訂されたため, 現在では「人を対象とする医学系研究 に関する倫理指針（統合指針）」を遵守することになった。 また，一般社団法人機能性食品開発支援機関協議会では, 食品のヒト試験に関する自主ガイドラインを 2011 年に縓 

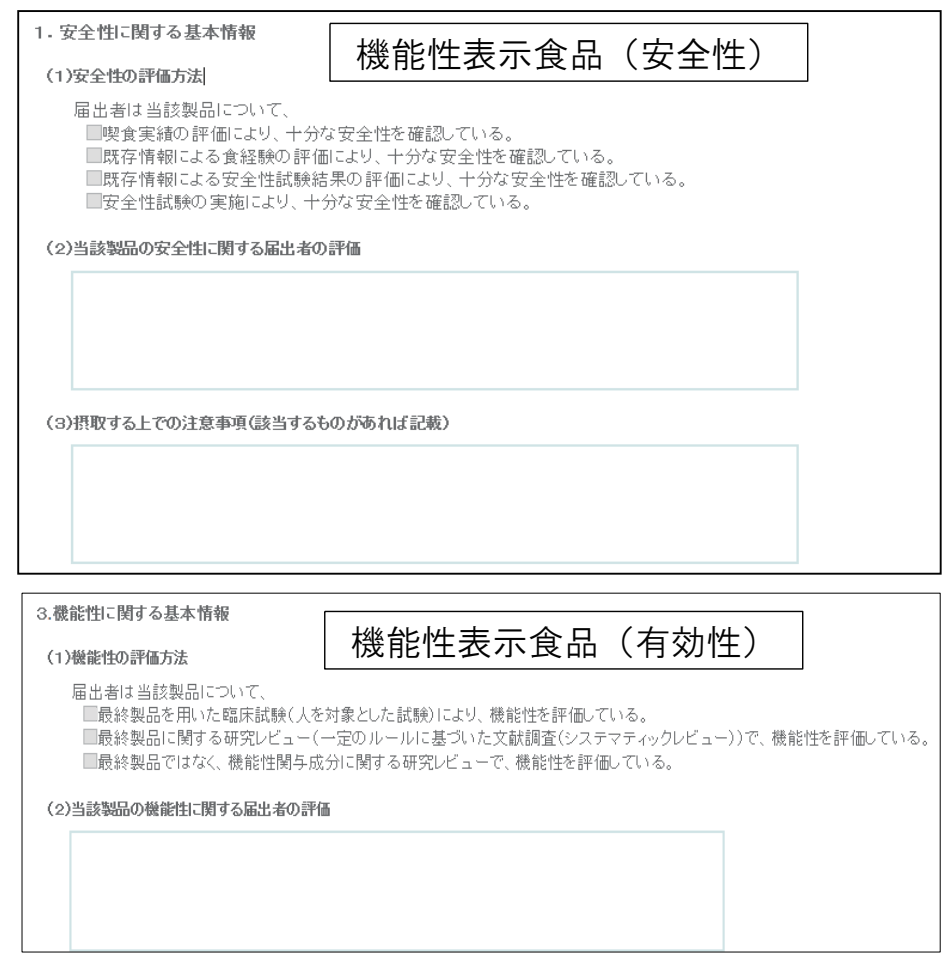

機能性表示食品の届出情報検索（https://www.fld.caa.go.jp/caaks/cssc01/）

図 5 機能性表示食品の一般消費者向け構造化抄録

めていたが ${ }^{21)}$, 統合指針が出されたことにより 2016 年に その自主ガイドラインを改訂した ${ }^{22)}$.このガイドラインは, 臨床試験の透明性と信頼性の確保を目的としている。

\section{7）国際規格の策定状況}

消費者の健康を守ること及び各種規制の国際調和を目的 にコーデックス委員会 (Codex Alimentarius Commission) が 1962 年に設立された。これは，食料農業機関 (FAO) と 世界保健機関 (WHO) による合同食品規格委員会として設 置され，日本は 1966 年より参加している ${ }^{23)}$.コーデック ス委員会におけるガイドラインの作成手順は, Steplの課 題の設定から Step8 の規格としての採択まである。また， 安全性評価に関する国際基準策定は，コーデックス委員会 とは別に FAO/WHO 合同食品添加物専門家会議 (JECFA) で行われている。これらの委員会を通して，この分野での 国際的なハーモナイゼーションが進んでいる。臨床試験の 重要性は記載されるが，介入試験を許可要件として含める かは各国による ${ }^{24)}$.

\section{6. 安全性又は有効性の根拠となる臨床試験における評 価系 - 医薬品と機能性表示食品との比較 -}

次に，医薬品と機能性表示食品それぞれにおける安全性 又は有効性の評価系を比較した上で, 機能性表示食品にお ける臨床試験に関する規制の特徵やその潜在的な課題を解 説する.

ただし，機能性表示食品の届出等に関するガイドライ ン $^{13)}$ は, 安全性又は有効性の根拠となる臨床試験におけ る評価に関して「特定保健用食品の表示許可等について」
(平成 26 年 10 月 30 日付け消食表第 259 号) を参照する, との記述があるため, 当該比較は医薬品と臨床試験が必要 となる保健機能食品との比較, と読み替えすることが可能 である。

1 ）安全性の根拠

(1) 機能性表示食品

機能性表示食品の届出等に関するガイドライン ${ }^{14}$

-（II）安全性に係る事項，第 2 安全性試験に関 する評価方法, 2. 安全性試験の実施による評価, (2) 臨床試験

「特定保健用食品の表示許可等について」(平成 26 年 10 月 30 日付け消食表第 259 号）を参照し，過剩摄取 時及び長期摂取時における安全性を確認するための試 験を実施する。(下線は筆者らが付した.)

機能性表示食品では，必要に応じて，12 週間以上の長 期摂取の安全性や通常の 3-5 倍量を 4 週間摂取した場 合の安全性を評価するための試験が必要とされている. これに関して倫理的配慮に関する議論は見当たらない が，個別の検証が必要と考える.

図 6 で示した通り，12 週間以上の摂取期間を設定した 場合は, 長期摂取の安全性試験は保健用途に係る有効 性の確認試験と同時に実施することができる。しかし， 12 週間以上の摂取期間でない場合には, 別で安全性試 験を行う必要がある ${ }^{25)}$. 


\section{保健機能食品}

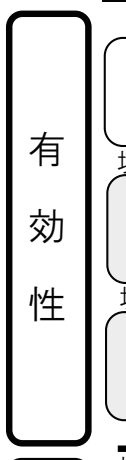

安

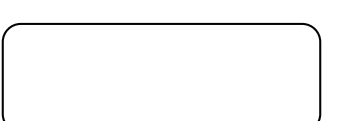

境界域を含む健常人

用量設定試験

境界域を含む健常人

保健用途に係る

有効性の確認

境界域を含む健常人

過剩摄取試験

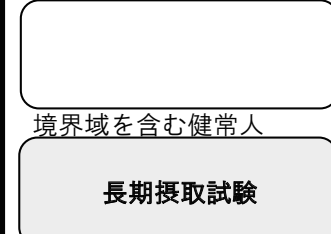

矦薬最

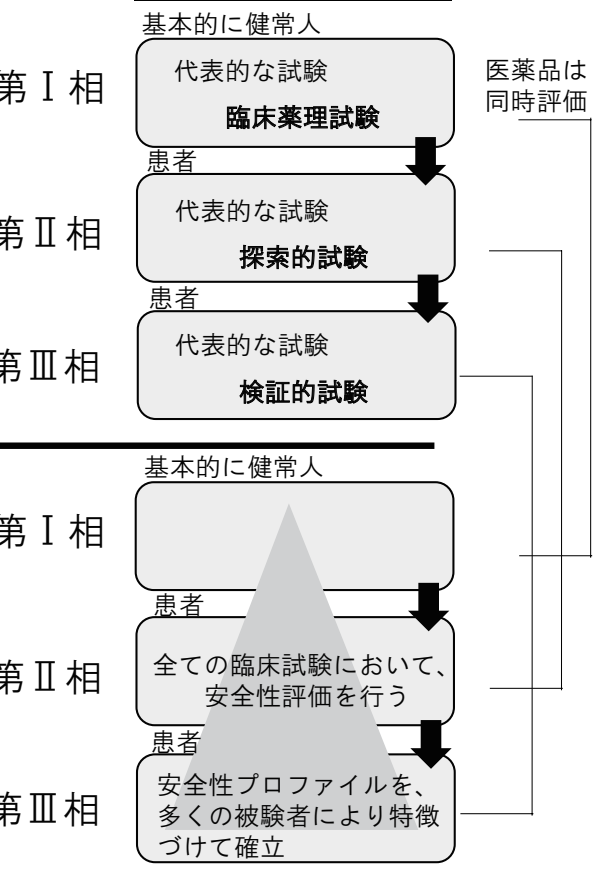

図 6 臨床試験を必要とする保健機能食品と医薬品の有効性又は安全性の評価系の違い 機能性表示食品の届出等に関するガイドライン ${ }^{13)}$ は, 安全性又は有効性の根拠となる臨 床試験における評価に関して「特定保健用食品の表示許可等について」(平成 26 年 10 月 30 日付け消食表第 259 号）を参照する，との記述があるため，当該比較は医薬品と 臨床試験が必要となる保健機能食品との比較，と読み替えすることが可能である.

(2) 医薬品

ICH E9 臨床試験のための統計的原則 ${ }^{26)}$

- VI. 安全性及び忍容性評価, 6.1 評価の範囲 すべての臨床試験において，安全性及び忍容性（用語集 参照）の評価は重要な要素である。初期の相では，こ の評価の大部分は探索的な性質のものであり，敏感に とらえられるのは明らかな毒性の出現のみである。し かし, 後期の相では, 被験薬の安全性及び忍容性のプ ロファイルを，より多くの被験者により十分に特徵づ けて確立することができる。（下線は筆者らが付した。）

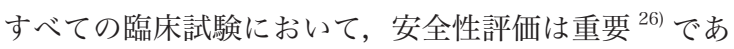
る。医薬品では，各相で有効性に加えて安全性も評価 する（図 6)。開発後期の相では，より多くの被験者に より十分に安全性プロファイルを特徵づけて確立する ことができる ${ }^{26)}$ ，とされ，承認取得を支持する安全性 又は有効性の十分な根拠の取得が行われる。

（3）医薬品と機能性表示食品の安全性の評価系の比較

機能性表示食品では, 図 6 で示した医薬品の検証的 試験にあたる保健用途に係る有効性の確認のための試 験において有効性と安全性を同時に評価することは可
能だと考える。しかし, 現在のガイドラインでは, 試 験期間が 12 週間以上でない場合は，保健用途に係る有 効性の確認のための試験とは別に長期摂取試験を行う 必要があるとされ ${ }^{25)}$, この点が医薬品の場合と考え方 が異なる。しかし，このような違いは，試験デザイン の工夫により解決するのではないかと考える。保健用 途に係る有効性の確認のための試験期間が 12 週未満で あれば，その有効性の確認のための二重盲検期間に加 えオープン試験である長期投与試験を続けて行い, 全 体の試験期間を 12 週間以上と設定するデザインも考え られる。この場合, 保健用途に係る有効性の確認と併 せて安全性を同時に評価できる.また, 医薬品の場合は, すべての臨床試験で安全性評価が重要な要素であると されているように，機能性表示食品においてもその考 え方が有用であるのかどうか，議論の余地はある。

2）有効性の根拠

(1) 機能性表示食品

機能性表示食品の届出等に関するガイドライン ${ }^{14}$

口（V) 機能性に係る事項, 第 1 表示しようとする機 能性の科学的根拠を説明するものとして必要な資 
料,（2）臨床試験の実施

臨床試験の実施方法（参加者の設定に係る考え方は除 く.）は原則として,「特定保健用食品の表示許可等に ついて」(平成 26 年 10 月 30 日付け消食表第 259 号) の別添 2 「特定保健用食品申請に係る申請書作成上の 留意事項」に示された特定保健用食品の試験方法 ${ }^{24)}$ (規 格基準型，疾病リスク低減表示及び条件付き特定保健 用食品に係る試験方法を除く.）（下記注）に準拠する こととする.

（注）試験は，食品の保健の用途に係る有効性及びその 摂取量を確認することを目的とし，原則として，設定 しょうとする一日摂取目安量による長期摄取試験を実 施する。なお，二日摂取目安量は，事前に検討された 用量設定試験の結果に基づいた量とする。（下線は筆者 らが付した.)

臨床試験により有効性を確認する必要がある。保健用 途に係る有効性の確認試験（医薬品の場合は，検証的 試験に該当）を行う前に，用量設定試験（医薬品の場 合は，探索的試験に該当）が必要とされている ${ }^{25)}$.

\section{(2) 医薬品}

ICH E8 臨床試験の一般指針 ${ }^{27}$

口 3 .開発の方法, 3.1 開発計画に関して考慮す べき点

3.1.3.1 第 I 相 (最も代表的な試験: 臨床薬理試験)

第 I 相は，治験薬を初めて人に投与することから 開始される。(‥略…) 第 I 相において実施される 試験は，通常，次の一つ又はその組合せの観点か ら行われる。a) 初期の安全性及び忍容性の推測 (… 略 $\cdots), b)$ 薬物動態 $(\cdots$ 略 $\cdots), \mathrm{c})$ 薬力学的な評価 $(\cdots$ 略 $\cdots)$, d) 初期の薬効評価 $(\cdots$ 略 $\cdots)$

3.1.3.2 第 II 相（最も代表的な試験：探索的試験） 第 II 相は，通常，患者における治療効果の探索を 主要な目的とする試験を開始する段階である。(… 略…）第 II 相における試験は，比較的均質な集団 になるように比較的狭い基準に従つて選択された 患者を対象として注意深く観察しながら行われる のが普通である。第 II 相の重要な目的は，第 III相 で行われる試験の用法・用量を決定することであ る. $(\cdots$ 略 $\cdots)$

3.1.3.3 第III相（最も代表的な試験：検証的試験） 第 III相は，通常，治療上の利益を証明又は確認す ることを主要な目的とする試験を開始する段階で ある。 $(\cdots$ 略…) このような試験は, 承認のための 適切な根拠となるデー夕を得ることを意図してい|
る。 $(\cdots$ 略 $\cdots)$ 第III相で実施されるこれらの試験に おいて，医薬品の適切な使用法を支持するのに必 要な情報（正式な製品情報）を得ることになる。 (下線は筆者らが付した.)

検証的試験で有効性を立証するには，プラセボ対 照試験等で優越性を示すこと又は用量 - 反応関係 を示すことが最も説得力がある ${ }^{26)}$. また，検証的 試験に先立ち, 臨床薬理試験で忍容性評価や薬物 動態等の検討を, 探索的試験では次の試験のため の用法用量の推測が行われる ${ }^{27)}$ (図 6).

（3）医薬品と機能性表示食品の有効性の評価系の比較 医薬品と機能性表示食品の場合とで大きな相違はな い. しかし，初めて人へ医薬品を投与する場合は，第 I 相試験で臨床薬理試験等が行われるのに対し, 機能 性表示食品ではそれに対応する臨床試験が行われてい ない．機能性表示食品の過剩摂取試験に対応するもの としては, 医薬品における初期の安全性及び忍容性の 推測が相当するが，過剩摂取試験は必ずしも実施され ていない.

\section{3) 有効性に係る臨床評価方法とその考え方}

次に, 医薬品と機能性表示食品において, 臨床試験での 有効性に係る臨床評価方法等をそれぞれ参照すべきガイド ライン ${ }^{14,26,27)}$ を用いて調査し，a)から n)の 14 個の項目別 に比較した（表 1)。両者で臨床評価方法の相違があったの は, 「 $\mathrm{g}$ ) 摂取期間」, 「h) 測定時期」, 「k) 被験者数」, 「l) 試 験食又は治験薬」,「m) 解析対象集団」, 「n) 保健の用途に 係る有効性等の判定方法又は統計解析」の 6 項目であった. 機能性表示食品が持つ臨床評価方法の特徵やその潜在的な 課題を明らかにするために, 上述の 6 項目について, 機能 性表示食品の評価方法に加え，医薬品の場合との比較とそ の差異を考察する。

(1)「g）摂取期間」又は「h) 測定時期」に関する相違 機能性関与成分の有効性評価では摂取期間は 12 週間であり摂取前を含め 4 週ごとに判定，と定め られているが ${ }^{25)}$, 医薬品では対象疾患や治験薬特 性に応じて決定する点が大きな違いである，食後 の血中中性脂肪の上昇といったような一部の領域 では機能性関与成分の有効性の評価は 12 週間では なく特性に応じて推奨される評価期間が設けられ ている ${ }^{25)}$. 今後, 異なる疾患や食品で一律に評価 が可能かどうか, 現在, 集積されつつある特定保 健用食品の実績に基づいた評価系の基準を設定し， ガイドラインへ反映することで，より適切な評価, 
審査の透明性確保，審査や開発のしやすさにも繋 がるものと考える.

\section{(2)「k) 被験者数」に関する相違}

医薬品の場合は，目標被験者数の算出のために, 有意水準, 検出力, 医学的に意味のある差, 及び 分散等，といった見積值が必要であることが明示 され，かつ被験者数の算出は主要な解析で用いる 解析対象集団に基づくべき，とされているのに対 し，機能性表示食品の場合は，それに該当する記 載がない.さらに，機能性表示食品の場合は，「必 要な数を一律に定めることは困難であるため，効 果の程度により, 必要な例数を求め, 被験者数を 確保する」といつた記載だけがあり，被験者数の 確保については基準がやや不明瞭になっていると 言える。則内 (2006) らの特定保健用食品の有効性 検証試験の質評価では，臨床試験における目標被 験者数の設定方法の記載は 36 試験のうちいずれに おいてもその記載はなかった ${ }^{28)}$ ，と報告されてい た。臨床試験の報告のための国際的ガイドライン であるCONSORT 声明 ${ }^{29)}$ においても，どのよう に目標被験者数を決定したのか, 記載が求められ ており，主要な解析を行う上でも被験者数の算出 は重要であるため，機能性表示食品でも目標被験 者数の算出の考え方を改めて検討し，その考え方 を公開することは制度の透明性確保のためにも必 要ではないかと考える。

\section{（3）「I）試験食又は治験薬」に関する相違}

現在，機能性表示食品では，機能性関与成分は同一 であるが最終製品でない食品を用いて，研究レビュー や臨床試験により機能性が評価されていることが多い. 最終製品でない状態の食品を人が摂取した試験結果 が，本来最終製品で得られるべき安全性や有効性のプ ロファイルを正確に反映しているかどうかは定かでは ない，例えば，複数の機能性関与成分が入っていても， それぞれの成分評価しかしていないものもあり，どの 成分が機能に関与しているか手探りの状況にあるので はないかと考えられる。

その点について山本 (2014) は「最終製品が機能性 関与成分以外に明らかに何らかの機能性を有する原材 料を含む場合は，最終製品の安全性や有効性について 個別で検討が必要である.」 ${ }^{30)}$ と述べている.

医薬品の場合，先発医薬品と同一の有効成分を含有 する後発医薬品では添加物等の違いから，例えば人で
の全身移行性が異なるといつた報告 ${ }^{31)}$ や主成分と含量 が同一であっても含有される添加物は同一でないため 薬効や吸収に影響を及ぼす可能性 ${ }^{32)}$ が指摘されている.

(4) 「m) 解析対象集団」に関する相違

医薬品では，解析対象集団の考え方が明記されてい る一方，機能性表示食品では触れられていなかった。 則内 (2006) らの特定保健用食品の有効性検証試験の質 評価の結果，臨床試験において割り付けられた全例を 解析するといつた ITT(Intent-to-treat) 解析*かどうか の記載は 36 論文のうち 2 報で記載があった ${ }^{28)}$, と報 告されていたが，この結果からは大多数の試験で解析 対象集団の定義がされていないことが推定される．例 えば，機能性表示食品の公開資料を確認すると本来対 象とはならない境界域を超えた被験者を試験責任医師 の判断の基に解析対象に含めるといった臨床試験も含 まれていた ${ }^{19)}$. 解析対象とする集団の定義が事前に定 められていない場合，評価者が意図した結果になるよ うに事後に解析対象集団を定めたと懸念を持たれる可 能性もあり，またそのことにより真の結果が歪む恐れ もあると考える。よって，事前にその定義を検討して おくことは重要である.

*: ICH E9 では次のように定義されている。「治療に用 いる治療方針により得られる効果は, 実際に受けた試 験治療ではなく，被験者を治療しょうとする意図（予 定した試験治療規定）に基づくことにより最もよく評 価できる，ということを主張する原則。この原則から， 一つの試験治療グループに割付けられた被験者は, 予 定した試験治療のコースを遵守したかどうかにかかわ らず, 割付けられたグループのまま追跡され, 評価され, 解析されるべきであることが導かれる.」 ${ }^{26)}$

(5)「n) 保健の用途に係る有効性等の判定方法又は統計 解析」に関する相違

医薬品では主要評価項目を一つにすべきといつた点 や安全性に関する項目が主要評価項目になり得る点が 食品との大きな違いである。例えば，「保健の用途ごと の試験の留意事項」の整腸関係の評価指標は, 排便回 数等 5 つの評価指標が記載されている ${ }^{25)}$. そのうちど れを主要評価項目とするのかは製品の特長によって検 討の余地があると考える、いずれにせよ, 主要評価項 目として選択した設定根拠が必要である。結果を見て からの後付け的な解釈にならないためにも評価項目に 関する事前の明確な設定は重要と考える，機能性表示 
食品では，有効性の判定において有意差が確認できる かどうかが重視されているが ${ }^{25)}$, 医薬品の場合では, それだけではなく治療効果の大きさに関する統計的推 定值を評価することの重要性も述べられている ${ }^{26)}$.こ れは，機能性表示食品の場合であっても必要な考え方 として採用すべきではないか，有意差が確認できたと しても臨床的に意味のある結果かどうかは別である。
この点につき, 則内 (2006) らの特定保健用食品の有効 性検証試験の質評価の中で, ”目標症例数の設定方法 や割付け結果の隠蔽, 介入のエフェクトサイズと精度 (95\%信頼区間) といった項目を中心に有効性を示すた めの十分な情報を含んだ論文報告がなされる必要があ る” ${ }^{28)}$ ，と指摘している.

表 1 有効性に係る臨床評価方法に関する医薬品と保健機能食品との比較

比較結果

a) 試験デザイン

O

b) ランダム化

O

c) 盲検化

0

保健機能食品 ${ }^{25)}$

医薬品 ${ }^{26,27)}$

並行群間試験を原則とするが，個人差の ばらつき, 関与成分の保健の用途, 試験 期間, 被験者数等を考慮し, 他の妥当な 方法を用いてもよい. 原則として無作為割付を行う必要がある

結果の客観性を確保する観点から, 試験 食摂取群とプラセボ食摂取群を対照とし た二重盲検比較試験

試験デザインについては, 結果の客観性 を確保する観点から, 試験食摂取群とプ ラセボ食摂取群を対照とした二重盲検比 較試験とする必要がある. $\triangle$

e) 評価指標
学会等により健康の維持・増進に対する 医学的及び栄養学的な意義が十分に評価 され，広く受け入れられているもの
検証的試験で最もよく用いられる試験計画は並行群 間比較計画である。被験者はそれぞれ異なる試験治 療が割り当てられている二つ以上の群の一つにラン ダムに割付けられる。 (ICH E9) 承認申請に利用することを目的とするほとんどの比 較臨床試験で標準的に採用すべき (ICH E9)

二重盲検試験が最適な方法である。(ICH E9)

有効性を立証するには，プラセボ対照試験でプラセ ボに優ることを示すこと, 実対照薬に優ることを示 すこと又は用量 - 反応関係を示すことが最も説得力 がある，優越性を示す目的以外にも，被験薬と標準 治療とが比較される場合がある。この型式の試験は 目的に応じて二つの主要なカテゴリに分けられる。 二つは「同等性」試験（用語集参照）で，もう一つ は「非劣性」試験（用語集参照）である。(ICH E9)

主要変数 (「目標」変数, 主要評価項目ともいう) は, 試験の主要な目的に直結した臨床的に最も適切で説 得力のある証拠を与えうる変数であるべきである. 主要変数は通常ただ一つにすべきである。ほとんど の場合，検証的試験の主要な目的は有効性に関して 科学的に説得力のある証拠を提示することにあるた め, 主要変数は, 通常有効性に関する変数となる。 $(\cdots$ 略…) 先行研究又は公表論文で使用された実績のあ る，信頼性及び妥当性の確立した変数を使用するこ とが薦められる。( ‥略…) (ICH E9)

疾患領域ごとに作成された臨床評価ガイドラインに 記載されている. 対象疾患や治験薬により異なる. 承認申請書に添付すべき資料の編集方法及び当該資 料を作成するための試験の指針等, PMDA の業務に 関連する主なガイダンス・ガイドラインとして「臨 床評価方法に関するガイドライン」で疾患毎に定め られている場合がある。

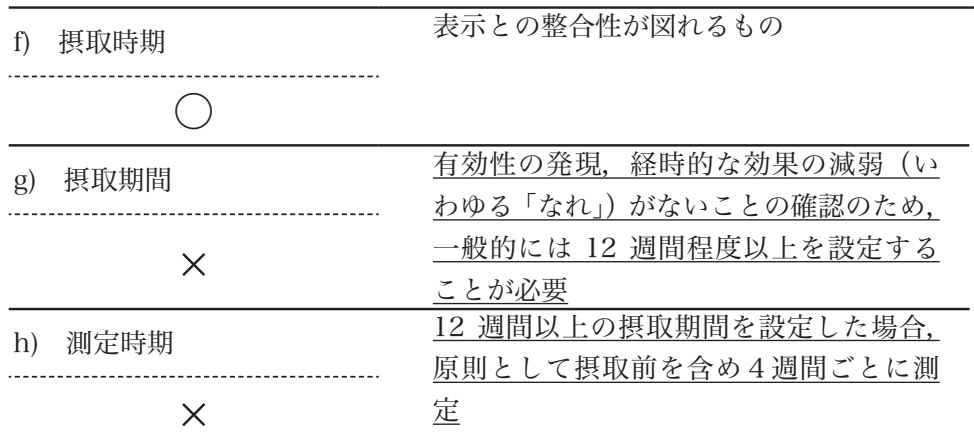




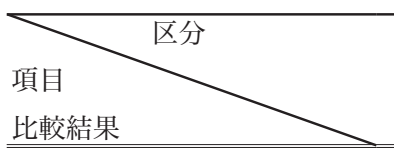

保健機能食品 ${ }^{25}$

健常人から疾病の境界域の者に至るまで

i) 被験者

O

の対象として適切な者. 有効性に関する 試験は，表示の対象とする摂取者層に対 する効果を確認することが第一の目的で あるので, 申請に当たっては, 主な摂取 者層での有効性を確認することが必要.

j）対照群の選択

$\triangle$

試験デザインについては, 結果の客観性 を確保する観点から, 試験食摂取群とプ ラセボ食摂取群を対照とした二重盲検比 較試験とする必要がある。
範讲において，目的とする保健の用途

医薬品 ${ }^{26,27}$

初期段階の試験で被験者となる患者集団又は健康志 願者集団は，厳格な選択条件によって狭い範囲に限 定されるだろうが，医薬品の開発段階が進むにつれ て，被験者の集団はその医薬品が目標とする患者集 団を反映するよう拡大されるべきである。(ICH E8)

試験には適切な対照群が必要である，比較にはプラ セボ，無処置，実薬対照又は被験薬の異なった用量 等が用いられる、対照の選択は，何よりも試験の目 的によって決めら机る (ICH E9, E10 各ガイドラ イン (別表) 参照). (ICH E8)

試験内容や実施方法により必要な数を一 律に定めることは困難である。効果の程 度により, 必要な例数を求め, 被験者数 k) 被験者数 を確保する.したがって, 統計学的手法上, 有意差検定に不十分な被験者数の場合に は，報告例として扱うものとする。また， 層別解析を行ったときに各層で有意差検 定に十分な被験者数（試験食摄取群，プ ラセボ食摂取群ともに）を確保できるよ うにする。

$\times$

試験食は，原則として申請食品を用いる. ただし，関与成分と申請食品との差異が 極めて少ない場合，その他合理的な理由 がある場合には，申請食品ではなく関与 成分で実施してもよい。

記載なし

m) 解析対象集団
被験者数を計算する方法は,計算に用いる見積值 (分 散，平均值，反応割合，イベント 発生率，検出すべ き差) とともに，治験実施計画書に定めておくべき である、また，これらの見積值の根拠も示すべきで ある。( ( ․略…) 検証的試験では，通常これらの仮 定は公表されたデー夕又は先行する試験の結果に基 づくべきである。( (‥略…) 慣例的に，第一種の過

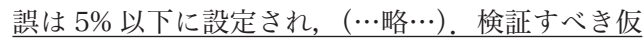
説のもつともらしさ及び検定結果に望む影響力の強 さにより，第一種の過誤の的確な選択に影響が及ぼ 〜20\%に設定される. (‥略…). 被験者数の計算は, 主要な解析で用いる解析対象集団に基づくべきであ る. (ICH E9) されるであろう。第二種の過誤は，慣例として $10 \%$

Intention-to-treat の原則（用語集参照）は，ランダ ム化が行われた全被験者を主要な解析に含めるべき であると主張するものである。 $(\cdots$ 略…) 多くの臨 床試験において, 最大の解析対象集団を用いること は保守的な戦略となる。.また多くの状況で，最大の 解析対象集団により得られる試験治療の効果の推定 值は，後の日常診療での効果を反映する可能性がよ り高いといってょい，検証的試験では，最大の解析 対象集団の解析と治験実施計画書に適合した対象集 団の解析との相違を明示的な議論と解釈の対象にで きるよう，通常両方の解析を計画することが適切で ある. 解析対象集団の変更により結論がどの程度変 わり易いかを，更に探索する計画を立てた方が望ま しい場合もあろう。最大の解析対象集団の解析と治 験実施計画書に適合した対象集団の解析が本質的に 同じ結論に達する場合，試験結果の信用度は高くな る. (ICH E9) 


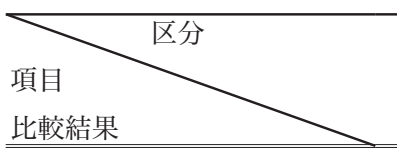

n) 保健の用途に係る有効性等 の判定方法又は統計解析
保健機能食品 ${ }^{25}$

医薬品 ${ }^{26,27)}$
原則として試験計画書に記載した解析計 画に従うこととし, 必ず統計学的処理に 上る有意差検定により行うこと。有意差 検定は, 通常, 事前に設定した危険率（1％ 又は $5 \%$ ）による検定を行い，試験食摂 取群とプラセボ食摂取群との群間比較の 差で評価する。 $(\cdots$ 略…) 評価指標が複数 ある場合の有効性判定は, 保健の用途に より異なるが，必ずしも，全ての評価指 標において有効性を示す必要はなく, 栄 養学的, 生理学的な意義を考慮したうえ で，あらかじめ試験計画書で設定した評 価指標により有効性を示すこと.
主要変数については（望むべくは副次変数について も)，これらの目的を果たすための作業に用いる統 計手法を記述すべきであり，基礎となる統計モデル を明確にすべきである，試験治療の効果の推定值は 可能な限り信頼区間とともに提示すべきものである (‥略…) 選択する個別の統計モデルには, 試験の 計画段階での統計的な配慮を反映させると同時に, 解析する変数に関する現在の医学的及び統計的知識 を反映させるべきである。( $(\cdots$ 略 $\cdots)$ 試験治療効果 の大きさに関する統計的推定値を，(有意性検定に 加えて) 信頼区間とともに示すことが必要だと心得 ておくことが重要である。(ICH E9)

機能性表示食品の届出等に関するガイドライン ${ }^{13)}$ は, 安全性又は有効性の根拠となる臨床試験における評価に関して「特定 保健用食品の表示許可等について」(平成 26 年 10 月 30 日付け消食表第 259 号) を参照する, との記述があるため, 当該比 較は医薬品と臨床試験が必要となる保健機能食品との比較，と読み替えすることが可能である.

保健機能食品は「別添 2 特定保健用食品申請に係る申請書作成上の留意事項 $\left.{ }^{25)}\right\lrcorner よ り$, 医薬品は「International Conference on Harmonisation of Technical Requirements for Registration of Pharmaceuticals for Human Use (ICH) E8 臨床試験の

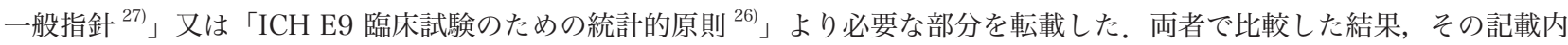
容に相違がない場合は $\bigcirc$, 少し相違がある場合は $\triangle$, 大きな相違がある場合は $\times$ と分類し, 相違がある該当箇所へ下線を付した.

4）保健の用途ごとの試験の留意点

(1) 機能性表示食品

別添 2 「特定保健用食品申請に係る申請書作成上の留意 事項」

5 保健の用途ごとの試験の留意事項

当該試験に関し，代表的な保健の用途ごとの試験の留

意事項について，これまで既許可品の審査過程において

蓄積した考え方を示すので参考にされたい。（下線は筆 者らが付した.）

次の保健の用途 1) コレステロール，2) 中長期的な血中 中性脂肪，3) 食後の血中中性脂肪の上昇，4) 血圧，5) 食後の血糖上昇，6) 体脂肪，7) 整腸，においては，今 までの特定保健用食品における審査の過程で蓄積された 評価に関する考え方（試験方法，評価指標，摂取期間， 対象被験者, 被験者数) が示されている（表 2).

\section{(2) 医薬品}

全てではないが疾患領域ごとに承認申請書に添付す べき資料を作成するための試験の指針等, 医薬品医療 機器総合機構 (PMDA)の業務に関連する主なガイダン ス・ガイドラインが作成され，厚生労働省より通知 ${ }^{9}$ として出されている，例えば，「睡眠薬の臨床評価方法 に関するガイドライン」といったものがある.

（3）医薬品と機能性表示食品の有効性の評価系の比較 機能性表示食品の「保健の用途ごとの有効性に関す
る試験のガイドライン ${ }^{25)} 」 の$ 特徵としては, 評価方法 はいつの時点で有効性の評価をどのように行うのか, 評価指標について主要評価項目や副次評価項目別の記 述は求められず，複数指標が併記されている場合もあ る。このガイドラインにおいては, 食後の血糖上昇の 評価においては，30，60，90，120 分の各時点で食 後血糖の推移を測定する（表 2) ことになってはいる が，いずれの時点の測定結果を主たる評価に用いるか の記載がない ${ }^{25)}$ ，そのため，食後の血糖上昇を抑える 根拠として評価に用いた最終的な測定時期が 120 分よ り短めになっており，それ以降のデー夕は提示されて いない食品もあった。一方で，コレステロール関係の 試験の場合は，食品の評価指標では「LDL コレステロー ル 25)」とある（表 2) が, 医薬品の場合は, いずれの試 験においても評価指標に加えて「12 週又は 24 週時にお ける LDL-C のベースラインからの変化率」と評価時期 やどのような評価を行うのかも定義されていた（表 3). また, 特定保健用食品の認可実績例が増えつつあるこ とを考慮すると, これら臨床試験の経験によるノウハ ウの蓄積で得られた事項をこのガイドラインへ反映さ せることで, 解析の際に都合の良い解析や解釈を防ぐ ことが可能である.

\section{7.おわりに - これらの違いを機能性表示食品における臨 床試験にどう活かすのか -}

2017 年 4 月現在, 833 件の機能性表示食品が消費者庁 
表 2 有効性に関する評価指標等＼cjkstart機能性表示食品

\begin{tabular}{|c|c|c|}
\hline 保健用途 & 主要な評価指標（評価方法） & 試験期間 \\
\hline 1 コレステロール & LDL コレステロール & 12 週 \\
\hline 2 中長期的な血中中性脂肪 & 中性脂肪 & 12 週 \\
\hline 3 食後の血中中性脂肪の上昇 & $\begin{array}{l}\text { 中性脂肪 } \\
\text { 血中濃度曲線下面積 (AUC) }\end{array}$ & $\begin{array}{l}\text { 摂取前 } \\
\text { 摂取後 2,3,4,6 時間後 }\end{array}$ \\
\hline 4 血圧 & 外来血圧 & 12 週 \\
\hline 5 食後の血糖上昇 & $\begin{array}{l}\text { 食後血糖 } \\
\text { 血中濃度曲線下面積 (AUC) }\end{array}$ & $\begin{array}{l}\text { 摂取前 } \\
\text { 摂取後 30,60,90,120 分後 }\end{array}$ \\
\hline 6 体脂肪 & 腹部脂肪面積, BMI, 腹囲 & 12 週 \\
\hline 7 整腸 & 排便回数, 排便量, 便性状, 粪便菌叢 & 2 週以上 \\
\hline
\end{tabular}

いずれも評価方法は, 「別添 2 特定保健用食品申請に係る申請書作成上の留意事項 ${ }^{25} 」 に$ に記載なし.

表 3 有効性に関する評価指標等＼cjkstart医薬品 ”コレステロール”の場合の例

\begin{tabular}{|c|c|c|}
\hline $\begin{array}{l}\text { 対象疾患名 } \\
\text { (Clinical Trial ID) }\end{array}$ & 主要な評価指標（評価方法） & 試験期間 \\
\hline 脂質異常症 & $\begin{array}{l}\text { BQ 法による LDL-C のベースラインからの変化率（24 週間投与し } \\
\text { た際のLDL-C をベースラインと此較する) }\end{array}$ & $\begin{array}{l}24 \text { 週の二重杳検および } 64 \text { 週間 } \\
\text { の非盲検継続投与試験 }\end{array}$ \\
\hline $\begin{array}{l}\text { 高コレステロール血症 } \\
\text { (NCT02260635) }\end{array}$ & $\begin{array}{l}\text { Percent Change from Baseline to Week } 12 \text { in Low- } \\
\text { Density Lipoprotein Cholesterol (LDL-C) Measured by Beta } \\
\text { Quantification (Time Frame: Baseline, Week 12) }\end{array}$ & $\begin{array}{l}12 \text { 週の三重盲検拉よび } 40 \text { 週の } \\
\text { 非盲検継続投与試験 }\end{array}$ \\
\hline $\begin{array}{l}\text { 高コレステロール血症 } \\
\text { (NCT02260648) }\end{array}$ & $\begin{array}{l}\text { Percent Change from Baseline to Week } 12 \text { in Low- } \\
\text { Density Lipoprotein Cholesterol (LDL-C) Measured by Beta } \\
\text { Quantification (Time Frame: Baseline, Week 12) }\end{array}$ & 12 週 \\
\hline $\begin{array}{l}\text { 高コレステロール血症, } \\
\text { 家族性高コレステロール血症 } \\
\text { (NCT02550288) }\end{array}$ & $\begin{array}{l}\text { 治療期 } 12 \text { 週時における LDL-C のベースラインかからの変化率（12 } \\
\text { 週時での LDL-C 值を評価する） }\end{array}$ & 12 週 \\
\hline $\begin{array}{l}\text { 高コレステロール血症 } \\
\text { (NCT02741245) }\end{array}$ & $\begin{array}{l}\text { LDL-C のベースラインからの変化率 (ベースラインと投与 } 12 \text { 週後 } \\
\text { のLDL-C の変化率を調査する) }\end{array}$ & 12 週 \\
\hline
\end{tabular}

医薬品情報データベース (http://www.clinicaltrials.jp/user/cteSearch.jsp) にて，全文検索を”コレステロール”と入力し， 試験タイプ・フェーズを”フェーズ 3 (第 3 相臨床試験) ”を選択した場合の検索結果である.その結果，14 件が抽出され， その後, 検証的試験が行われた 5 試験について綯めた。(2016 年 12 月 1 日現在)

の機能性表示食品の届出情報検索データベースで公開され ている ${ }^{19)}$ ，そのうち最終製品を用いた臨床試験により機能 性を評価しているものは 48 件であった。つまり，機能性 表示食品全体の $5.8 \%$ の食品のみでしか臨床試験で申請さ れていない. その他, 大多数の食品は研究レビューや既存 の情報により安全性及び有効性が評価されているが, 臨床 試験における科学的に妥当で信頼できる評価系に焦点を置 いた考察はより重要であると考える，機能性表示食品の市 場はより成長が見込まれるため，研究レビューといつた既 存情報だけでは対応できない新たな 3 次機能を持つ保健機 能食品が増えてくるかもしれない。 そのような場合, 臨床 試験により安全性と有効性を示すことが必要となる。さら に, 科学水準や社会における考え方も時代が進むにつれて 進化する。つまり，現在の新しい科学基準だと無効と判定 されるような食品が出てくる可能性もある，実際，医薬品 の場合では, 市販後の有効性に関する再評価で市場撤退し
た製品 ${ }^{33)}$ があった。また, 消費者委員会 (2016) は, 「(試験) 水準の変更前に許可を受けた製品の有効性や安全性を再評 価し, 新しい基準でも科学的根拠を十分説明することがで きるかどうかを確認することは，科学の考え方からしても， また消費者，企業にとっても重要なことである ${ }^{13)} 」 と$ 述心゙ ている。 また再評価の重要性は「栄養及び健康強調表示の

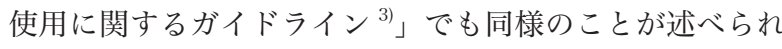
ている．今後，再評価が必須となった時代が到来すれば, 過去の研究レビュー等の既存情報というよりは臨床試験で の安全性及び有効性の評価によって, その商品の付加価值 となる科学的根拠を証明することになるのではないか.

しかし，現状としては，機能性表示食品制度は，多額の 費用を要するとされる臨床試験を実施しなくても届出が可 能である、ここが，中小企業の参画も可能としたこの制度 の優位な点であると考える.つまり早急に臨床試験の必要 性を訴えるということではなく，段階的に保健機能食品産 
業を良くする制度が重要であると考える。そのためにも， 臨床試験における安全性又は有効性に関する評価系を議論 し深化させることは，規制制度を厳しくするといつたこと が目的ではなく，透明性のある明確化された制度や基準と して確立させることが目的であり，消費者からの厚い信頼 の獲得とさらなる市場の活性化に繋がると確信する.

\section{参考文献}

1) Roberfroid MB. Global view on functional foods: European perspectives. The British journal of nutrition 2002; 88 Suppl 2: S133-138.

2) 清水俊雄。食品機能の表示と科学 機能性表示食品を理解 する。東京，同文書院， 2015 .

3) 国際連合食糧農業機関 (FAO) 及び世界保健機関 (WHO) 厚生労㗢省訳。栄養及び健康強調表示の使用に関するガイ ドライン 2013; CAC/GL 23-1997 http://www.mhlw.go. jp/topics/idenshi/codex/06/dl/cac_gl23.pdf. Accessed 14 December, 2016.

4) 金森修, 中島秀人 (編著). 科学論の現在. 東京. 勁草書房. 2002.

5) 矢野俊正. 2.「食品機能の系統的解析と展開」について。化 学と生物 1987; 25(2): 110-113.

6) 小田嶋文彦.【機能性表示食品の評価】機能性表示食品制度 の意義と課題．ファルマシア 2016; 52(6): 515-519.

7) 細谷憲政，林裕造，上野川修一 (監修), 財団法人日本健康· 栄養食品協会 (編). 食品保健の科学. 東京. 丸善株式会社. 2010.

8) 消費者庁. 第 4 回 食品の新たな機能性表示制度に関する検 討会資料 4 食品の機能性表示に関する消費者意向等調査 結＼cjkstart果 2014; http://www.caa.go.jp/foods/pdf/140404_ shiryo_4_1.pdf. Accessed 1 December, 2016.

9) 厚生労働省. 無承認無許可医薬品の指導取締りについ て. 1971; 薬発 476 号 :http://www.mhlw.go.jp/kinkyu/ diet/dl/torishimari.pdf. Accessed 1 December, 2016.

10) Swinbanks D, O'Brien J. Japan explores the boundary between food and medicine. Nature 1993; 364(6434): 180.

11) Contor L. Functional Food Science in Europe. Nutrition, metabolism, and cardiovascular diseases : NMCD 2001; 11 (4 Suppl): 20-23.

12) 北海道経済部食関連産業室。北海道食品機能性表示制度 について. 2013; http://www.pref.hokkaido.lg.jp/kz/sss/ ks/hyouziseidogaiyou.pdf. Accessed 1 December, 2016.

13）消費者委員会。「特定保健用食品等の在り方に関する専門 調査会」報告書. 2016; http://www.cao.go.jp/consumer/ iinkaikouhyou/2016/doc/20160331_tokuhoarikata_ houkokul.pdf, http://www.cao.go.jp/consumer/ iinkaikouhyou/2016/doc/20160331_tokuhoarikata_ houkoku2.pdf, http://www.cao.go.jp/consumer/ iinkaikouhyou/2016/doc/20160331_tokuhoarikata_ houkoku3.pdf. Accessed 14 December, 2016.

14) 消費者庁. 機能性表示食品の届出等に関するガイドライン. 2016; 消食表第 234 号 :http://www.caa.go.jp/foods/pdf/ food_with_function_clains_guideline.pdf. Accessed 14 December, 2016.

15) 内閣府. 規制改革実施計画. 2013; http://www8.cao.go.jp/ kisei-kaikaku/kaigi/publication/130614/item l.pdf. Accessed 1 December, 2016.

16) 矢野経済研究所. 2016 年版 企業参入が進む機能性農産物 の開発動向と市場展望 〜新たな機能性表示制度で注目さ れる農産物の差別化戦略とは〜。東京. 矢野経済研究所。 2016.

17) 速水耕介, 都築繁利, 渡邊泰雄.【機能性表示食品の評価】 食品の機能性に関するエビデンスの検証＼cjkstart臨床試験の実施 と解析における応用. ファルマシア 2016; 52(6): 525-529.

18）天ケ瀬晴信.【機能性表示食品の評価】米国における臨床薬 理学的視点に基づく食品の機能性の考えかた. ファルマシ ア 2016; 52(6): 520-524.

19）消費者庁. 機能性表示食品の届出情報検索. 2015; https:// www.fld.caa.go.jp/caaks/cssc01/. Accessed 1 December, 2016.

20)くすりの適正協議会. 健康食品・医薬品の知識と意識に関 する調查. 2016; https://www.rad-ar.or.jp/information/ pdf/nr15-160309.pdf. Accessed 1 December, 2016.

21）一般社団法人機能性食品支援機関協議会. 食品のヒト試験 に関するFFDAのガイドライン。健康・栄養食品研究 2013; 14(2): 23-28.

22) 一般社団法人機能性食品支援機関協議会. 食品のヒト試験 に関するFFDAの新自主ガイドライン。健康・栄養食品研 究 2016; 15(1): 1-11.

23) 清水俊雄. 食品安全の制度と科学. 1 ed. 東京. 同文書院. 2006.

24）清水俊雄. プロバイオティクスに関する健康表示の国際比 較. 日本乳酸菌学会誌 2010; 21(2): 122-129.

25) 消費者庁. 別添 2 特定保健用食品申請に係る申請書作成 上の留意事項 2014; 消食表第 259 号 :http://www.caa.go. jp/foods/pdf/syokuhin1567.pdf. Accessed 1 December 2016.

26) 厚生労働省. 臨床試験のための統計的原則. 1998; https:// //www.pmda.go.jp/files/000156112.pdf. Accessed 1 December, 2016.

27）厚生労働省. 臨床試験の一般指針．1998; https://www. pmda.go.jp/files/000156372.pdf. Accessed 1 December, 2016.

28) 則内友博, 大橋靖雄. 特定保健用食品の有効性検証試験 の論文報告 CONSORT 声明を用いた質評価. 薬理と治療 2006; 34(10): 1039-1051.

29) 上岡洋晴, 津谷喜一郎。補完代替医療とエビデンス (Vol.13) 
ランダム化並行群間比較試験報告のためのガイドラインと

くに薬剂以外を対象とする場合の考元方。医学のあゆみ 2015; 254(12): 1136-1140.

30) 山本哲郎．新たな機能性表示に求められる健康食品の安全 性および有効性。薬理と治療 2014; 42(9): 625-629.

31）阿波圭介，佐藤宏樹，堀 里子ら，ケトプロフェンテープ先 発・後発医薬品の全身移行性の in vitro放出試験による予測. 薬学雑誌 2012; 132(1): 135-144.
32) 加藤洋美, 吉井美智子, 小澤光一郎. 後発医薬品の適正使 用と医薬品添加物に関する研究. 薬学雑誌 2007; 127(12): 2035-2044.

33）厚生労衝省。2016 年 3 月 17 日 薬事・食品衛生審議会 医薬品再評価部会 議事録. 2016; http://www.mhlw.go.jp/ stf/shingi2/0000134530.html. Accessed 1 December, 2016.

\title{
ABSTRACT \\ Differences on the Regulation between Foods with Health Claims and Ethical Pharmaceuticals from the Viewpoint of Regulatory Science
}

\author{
Nanae TANEMURA ${ }^{1}$, Naobumi HAMADATE ${ }^{2}$, Hisashi URUSHIHARA ${ }^{1, *}$ \\ ${ }^{1}$ Division of Drug Development \& Regulatory Science, Faculty of Pharmacy, Keio University \\ ${ }^{2}$ Hamadate Science Office
}

\begin{abstract}
Currently, self-medication, including the use of foods with health claims (FHCs), is promoted as means of increasing our health span. However, the functional substance(s) in FHCs and its actions are diverse, and therefore it is difficult to evaluate their safety and efficacy in clinical trials. In this review article, we describe the definition and the history of regulations regarding FHCs. After discussing their types and features, we explain the differences on regulations between FHCs and ethical pharmaceuticals regarding their safety and efficacy in clinical trials, which are required to provide them with scientific evidence. Finally, we believe that transparent standards regarding the evaluation of FHCs would help increase the use of FHCs and their market value in the future.
\end{abstract}

Key words: regulatory science, health claim, food with health claims, ethical pharmaceuticals, efficacy, safety, evaluation, clinical trials, food, Japan 